\title{
Hybrid securities and commodity swaps; tools to hedge risk in emerging stock markets: Theoretical approach
}

\author{
Naser I. Abumustafa \\ Department of Finance and Economics, Gulf University for Science and Technology, \\ Kuwait. \\ Tel: (965) 2240130, ext. 5540, E-mail: Drnaser69@hotmail.com
}

Received (in revised form): 12th December, 2006

\begin{abstract}
Naser I. Abumustafa, Associate Professor of Finance, is the acting director of the MBA programme at Gulf University for Science and Technology (GUST). He has an international reputation as an expert on Middle Eastern stock markets, especially Gulf Cooperation Council stock markets. His research, teaching, and consulting addresses regulatory and practitioner issues in risk trading and in investment management. He has written extensively about trading rules, transaction costs, index markets, and stock markets regulation and efficiency. He is the author of 12 articles in leading scholarly journals, including Applied Financial Economics, Development Journal, Journal of Applied Economics Letters and Risk Management Journal. He serves as a member of the Editorial Advisory Board for the International Research Journal of Finance and Economics and Journal of Middle Eastern Finance and Economics.
\end{abstract}

\section{Practical applications}

The use of derivatives in corporate risk management has grown rapidly in recent years, fuelled in part by the success of the financial industry in creating a variety of over-the-counter and exchange-traded products. Although the types of risks confronting managers vary across industries, there is substantial commonality in the underlying rationale for the use of derivatives and the financial engineering techniques that are employed. Managerial risk aversion and incentive issues are important practical rationales for risk management in the investment industry. A substantial proportion of the firms in the industry are closely-held stocks and mutual companies, where managers are likely to exhibit risk aversion because of suboptimal diversification of corporate wealth, organisation-specific capital, and/or the absence of effective mechanisms for owners to use as disciplining devices.

\begin{abstract}
This study presents hybrid securities and commodity swaps as a diversification channel in emerging stock markets, in particular, Gulf Cooperation Council (GCC). It is evident that derivative markets play a crucial part in the global financial system. The use of hybrid securities as a tool to hedge risk in emerging stock markets has, however, not been closely examined. Hybrid securities can play a vital role in the future of
\end{abstract}

emerging stock markets. It may be considered a key capital management tool. The paper attempts to apply the appropriate mechanism of hybrid securities in emerging stock markets. Credit derivatives have many uses and provide flexibility to transfer and price credit risk more efficiently. The expected defaults in the GCC markets are expected to continue growing at a high rate. Credit derivatives are likely to be used more extensively in those situations where
Journal of Derivatives $\&$ Hedge Funds, Vol. 13 No. 1, 2007, pp. 26-32 (C) 2007 Palgrave Macmillan Ltd $1753-9641 \$ 30.00$ 
buying or selling in cash markets is cumbersome and less efficient.

Journal of Derivatives \& Hedge Funds (2007) 13, 26-32. doi:10.1057/palgrave.jdhf.1850060

Keywords: hybrid securities; commodity swaps; Gulf Cooperation Council emerging markets; credit derivatives

\section{INTRODUCTION}

Financial derivatives are one of the fastest growing classes of financial instruments, one of the most potentially useful and also one of the most misunderstood. When used strategically, they can effectively reduce risks and transaction costs. They can also be a tool for investors who wish to create extra yield or speculate on market conditions. Derivatives are not inherently bad, but they can be used very badly. Derivative strategies in securities lending transactions must be consistent with the scope and objectives of investor's programmes. They should be applied on a case-by-case basis according to the individual investor risk/return preferences. Some derivative strategies, though, may be perfectly acceptable to even the most conservative customers. Various types of floating-rate obligations, for example, add value by minimising interest rate risk. Other investors, particularly those who currently use derivatives within their investment framework, can use derivative strategies to exploit market inefficiencies. Asset swaps and total rate of return swaps are two common techniques for identifying and taking advantage of arbitrage opportunities.

A hybrid is a security that combines two or more different financial instruments. Hybrid securities generally combine both debt and equity characteristics. The most common example is a convertible bond that has the features of an ordinary bond, but is heavily influenced by the price movements of the stock into which it is convertible. In general, all hybrid securities are designed to provide issuers with a flexible financial approach that is provided by equity, and to minimise the intensity of shareholders' interests that is created by issuing common stock. These hybrids can generally be broken down into three broad categories: traditional preferred stock, optionally convertible securities and deferrable securities.

The traditionally preferred stock is the 'original hybrid' instrument with the longest dated history. It is considered hybrid because it combines the attributes of both a debt and equity instrument. Preferred stock is proclaimed to have a long-dated maturity of over 30 years. Certain types of traditional preferred stocks known as perpetual preferred stocks have no maturity; thus, over the life of the security, repayment and refinancing risks are minimal. They also have dividend payments which, unlike interest on debt, may be suspended without triggering a corporate default.

An optionally convertible security can be viewed as a straight preferred stock with an option that enables investors to convert the security into a predetermined number of shares of common stock, sometimes called 'CVs'. Convertibles typically include the following features: First, there is the 'strike price' or the common stock price at which the conversion option can be exercised; it is set higher than the existing stock price, thus placing the option 'out of the money'. If, over time, the stock price moves above the strike price, the option would be 'in the money' making a near-term conversion more likely. 
Secondly, there is the call feature, which enables issuers to call the securities after a given time period (often five years). The issuer's call option provides an incentive for investors to convert. Without it, most investors would prefer to continue to receive their interest and/or dividends on the security while still continuing to participate in the upside of the stock through the conversion option.

Finally, the added cash-flow flexibility, which is provided by convertible securities, is most valuable in times of distress. Since distress typically leads to declines in the issuer's stock price, conversion, however, rarely occurs when most needed by the issuer.

Issuing convertible bonds is one way for a company to minimise negative investor interpretation of its corporate actions. For example, if an already public company chooses to issue stock, the market usually interprets this as a sign that the company's share price is somewhat overvalued. To avoid this negative impression, the company may choose to issue convertible bonds, which the bondholders will very likely convert to equity anyway, should the company continue to do well, while from the investor's perspective, a convertible bond has a value-added component built into it.

One of the most popular hybrid securities among issuers and investors is deferrable securities. It has basic features that attract the most novice investors. It has a long-dated maturity, typically between 29 and 40 years, dividends and interest for up to five years on a cumulative basis. This is usually a sufficiently long time to allow issuers under financial stress to reorganise their finances and improve their cash flows, and it has a call option feature that can be exercised by the issuer. Hybrids can also function differently. One source of potential issuer demand is from companies facing shareholder calls for increased dividends and share buybacks. Hybrids allow them to raise cash for such purposes without jeopardising their credit ratings. We think that hybrid securities will play a vital role in the future of finance; it will be considered a key capital management tool.

\section{Commodity swap}

Swaps are contract agreements that occur between two parties, in which both parties pledge to deliver payments to each other at specified dates in the future, and both use differing methods to identify the total payments that are due. A commodity swap is a swap by which one party provides a series of payments based on a price of some underlying commodity, and the other party provides a series of payments that are fixed or identified by a different floating price. Therefore, the parties are exchanging cash instead of the commodity itself. Commodity swaps are usually conducted to hedge against risks that cannot be hedged against by using futures contracts. These risks could be a geographical or quality basis risk, which is a risk that the value of a futures contract cannot move in line with the risk of the underlying commodity. The basis risk is the risk that the cash futures spread will either broaden or contract between the times that a hedging position is applied.

Commodity swap is a swap in which the payout to at least one counterparty is based on the price of a commodity or the level of a commodity index. Commodity swaps have been in existence since the mid-1970s and enable producers and consumers to hedge commodity prices. Usually, the consumer would be a fixed payer to hedge against rising input prices. 
The producer in this case pays floating-rate price (ie receiving fixed price for the product), thereby hedging against falls in the price of the commodity. If the floating-rate price of the commodity is higher than the fixed price, the difference is paid by the floating payer and vice versa.

Commodity swaps are becoming increasingly common in the energy and agricultural industries where demand and supply are both subject to considerable uncertainty. For example, heavy users of oil, such as airlines, will often enter into contracts in which they agree to make a series of fixed payments, say every six months for two years, and receive payments on those same dates as determined by an oil price index. Computations are often based on a specific number of tons of oil in order to lock in the price the airline pays for a specific quantity of oil, purchased at regular intervals over the two-year period. The airline will, however, typically buy the actual oil it needs from the spot market. Dynkin et al. ${ }^{1}$ investigate the ex post gains that come from different investment styles (eg yield curve timing versus security selection).

\section{Why commodity swap in GCC markets}

Oil producers operate in an environment subject to adverse price movement in the international oil market. This exposure to such risk is enough to increase a company's costs or dramatically reduce its profits. As risk exposure reduces the producer's appeal to investors and makes gaining access to debt markets more difficult, the need to efficiently manage exposure to fluctuating commodity prices is clearly one of the greatest challenges facing an exploration and production company today. Most of the commodity swaps engage in the commodity of oil. In 1986, the Chase Manhattan Bank was the first ever oil commodity swaps contract that was established. In this oil commodity swap, oil is used to show the amount that is due from each of the two parties instead of using cash. Oil swaps are very similar to a fixed-forfloating interest rate swap in the way that payments are made according to the oil prices that are fixed (for one party) and floating (for another party).

When putting a price on commodity swaps, one can think of the swaps as a series of forward contracts, though they are described by a couple of differences that are peculiar. Some of these peculiar differences are the cost of hedging, the institutional structure of the commodity being exchanged, the liquidity of the commodity market, seasonality and its effects on the commodity market, the changes in the futures of the bid-ask spread, the brokerage fees and the credit risk, capital and administrative expenses. This eccentricity of the commodity markets relates to the limited number of members in these markets, the distinctive aspects that control these markets, the interconnections with equivalent markets and the individual members of these markets.

The GCC money gusher is fed by many wellsprings, and one of them is fear. The market is justifiably worried about a massive disruption of oil supplies, possibly caused by a terrorist attack. This fear is pushing oil prices higher and sending additional billions into the coffers of oilproducing nations. Some cynics argue that oil producers welcome the fear of disruption because it boosts their revenue. The situation created an Asset bubble, which dominated all GCC financial markets over the past three years. The region is now in the midst of another bubble, this one in commodities. It, too, will 
burst. The only question is when. The surge in crude oil prices over the years is not a surprise to anyone. The super-cycle theory of ever-rising commodity prices is based on the false premise that GCC countries will stay the same course it has been on for the past three years. The GCC countries are unlikely to do that; a rebalancing towards slower growth will reduce its impact on global commodity prices and demand, and financial derivatives such as swaps and moreexotic investment tools can create a shield against risk from depreciating oil price for most GCC countries' investors.

\section{SUGGESTED STRATEGIES}

In this study, we discuss several strategies that investors in oil producer countries can use to manage their market risk. All of these strategies can be structured for a variety of international crude and products, hedging periods and protection levels can be customised to fit any maturity and price level. Hybrid investment strategies aim to bring investors the best of both worlds, and their popularity has been growing rapidly. In other words, hybrid strategies can be described as the adoption of hedge fund hedging techniques by the long-only world and the increasing use of over-the-counter (OTC) derivatives in products. But hybrid products also extend to equity-linked notes, volatility notes and structured credit products, among others.

Over the last couple of years, derivatives trading have been pushed before the securities and exchange board of the Kuwait stock exchange, which is the only stock exchange that deals with such tools in the GCC countries' stock markets. Derivatives trading, many predict, will spur growth in the underlying markets by offering a hedging facility and enticing more risk-averse investors into the system. The introduction of derivatives trading will separate leveraged positions from the spot markets and make it easier for exchanges to implement rolling settlement. This should reduce the volatility in the existing markets, and make risk containment and regulation easier by making markets safer.

\section{Credit derivatives}

Credit derivatives are privately negotiated bilateral contracts that allow users to manage their exposure to credit risk. This mechanism can be used for any debt instrument or a basket of instruments for which an objective default price can be determined. In this process, buyers and sellers of the credit risk can achieve various objectives, including reduction of risk concentrations in their portfolios and access to a portfolio, without actually making the loans. There are various traditional mechanisms to reduce credit risk, including refusal to make a loan, insurance products, guarantees and letters of credit, but these mechanisms are less effective during periods of economic downturn when risks that normally offset each other simultaneously default and financial institutions suffer substantial loan losses.

\section{Credit default swaps}

A credit default swap is another mechanism for distributing the default risk of securities and loans. It enables lenders and investors to improve risk management and better achieve their financial goals. In this case, one party makes periodic basis points payments and another party makes payments for the principal if the 'credit default' event occurs. The pricing of such a derivative depends upon the credit quality of the 


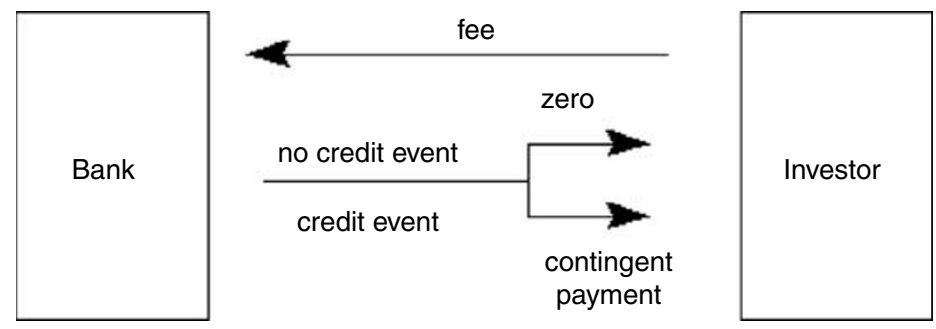

Figure 1: Credit default swap cash flows

reference credit, supply and demand for the reference credit and prevailing credit spreads. The objective might be any of the following: to sell a specific risk, for example country risk in a project finance transaction, to free up credit lines for a specific customer, to pick up additional yield by assuming the credit risk, to improve portfolio diversification, to gain exposure to credits without buying the assets or to assume an off-balance-sheet synthetic position. Figure 1 is a CDS cash flow.

\section{Hybrid Hedge fund strategies}

Hybrid mutual funds follow investment strategies similar to some popular trading styles employed by many hedge funds. Many hybrid mutual funds are 'bear funds', which means that they are mutual funds that go short, buy put options, use leverage or employ other strategies to increase in value as stocks decrease in value. Other categories of hybrid mutual funds, including market neutral, try to maintain low correlation with traditional asset classes and seek capital appreciation in both bull and bear markets; convertible arbitrage that engages in short sale of convertible securities' underlying stocks; merger and acquisition that invests in companies that are the subjects of a merger, takeover or a buyout; long/short hedge equity that uses short sale to hedge against market risk.
Since hybrid mutual funds follow investment strategies similar to some popular hedge fund strategies, they are able to provide risk and return opportunities similar to existing hedge funds. Fung and $\mathrm{Hsieh}^{2}$ demonstrate that hedge fund returns are also driven systematically by market factors such as changes in credit spreads or market volatility.

\section{Funds of funds}

These funds invest in other hedge funds and can be seen as being a more diversified version of the normal hedge funds with the opportunity to take on hedge fund exposure, albeit not directly. These funds essentially analyse hedge fund manager performance and ability rather than the actual investments within the individual hedge funds.

\section{Funds of funds of funds}

A new concept developed by a New Jerseybased hedge fund, funds of funds of funds (or F3s) aims to take on hedge fund exposure in terms of investable instruments while reducing the volatility of the fund itself. These F3s may allow investors with lower risk tolerances to take positions in the vastly mystifying hedge fund industry. 


\section{CONCLUSION AND RECOMMENDATIONS}

Credit derivatives have many uses and provide flexibility to transfer and price credit risk more efficiently. The expected defaults in the GCC markets are expected to continue growing at a high rate. Credit derivatives are likely to be used more extensively in those situations where buying or selling in cash markets is cumbersome and less efficient. Hybrid tools provide small investors unique risk-return opportunity not usually provided by most of the traditional investment vehicles. Hybrid tools can provide efficient diversification. They provide the investors with exposure to investment products with risk and return opportunities that most traditional tools fail to offer. As a result, some hybrid tools illustrate high sensitivity to equity market factors while other hybrid tools show little equity market sensitivity. Thus, various hybrid tools may be combined with traditional stock and bond portfolios to offer either risk reduction or enhanced return opportunities.

Derivatives, like most tools, are neutral until utilised. It is with utilisation that positive and negative attributes can be identified. The main utilisation issue related to the use of derivatives is the use to which the investor is applying derivative strategies - hedging or speculating. Hedging is generally perceived to be good and speculating is generally perceived to be bad. There are, however, three thoughts that should be kept in mind when considering these generalisations: (1) Hedging rationale and the related documentation is often cleverly utilised to disguise speculation. Therefore, the real issue is how to properly distinguish hedging from speculating. The key to distinguishing between hedging and speculating rests in investor discipline in consistently applying the precepts outlined in the foregoing risk investor process discussion. (2) Speculation is an inherent part of human behaviour, which, when managed properly, can produce very constructive results. Some entities are, however, precluded, by regulations or internal policies and procedures, from speculating with derivatives. The paradox of this is that these same entities, for the most part, are allowed to speculate through policy decisions and cash market transactions, and, furthermore, are, in effect, speculating when they are not hedged. Therefore, the issue becomes one of knowing when and how to properly speculate as a function of the business and regulatory environment within which the investor activity is taking place. (3) Regardless of whether the investor is hedging or speculating, there is one very dominant consideration inherent in both - prudent management of the risks associated with the underlying activity. We recommend the following to GCC countries' investors. (1) The use of derivatives in a manner consistent with the overall risk management and capital policies. (2) The adoption of consistent counterparty credit limits. (3) The use of a consistent measure to calculate daily market risk. (4) The conduct of regular simulations of stress-tests.

\section{References}

1 Dynkin, L., Hyman, J. and Wu, W. (2000) 'The Value of Skill in Security Selection Versus Asset Allocation in Credit', Journal of Porffolio Management, Vol. 27, pp. 20-41.

2 Fung, W. and Hsieh, D. (2002) 'Asset-Based Hedge Fund Styles and Portfolio Diversification', Financial Analysts Journal, Vol. 58, No. 5, pp. 16-27. 